\title{
Prevalence of viral, bacterial and parasitological diseases in rats and mice used in research environments in Australasia over a 5-y period
}

Elizabeth F. McInnes, BVSc, PhD, FRCPath, FIATP' ${ }^{1}$, Lorna Rasmussen, BVSc, DACVP, MMEdVet ${ }^{2}$, Peony Fung, MSc ${ }^{1}$, Amanda M. Auld ${ }^{1}$, Luisana Alvarez, BSc ${ }^{1}$, David A. Lawrence ${ }^{1}$, Morgan E. Quinn, BSc(Hons) ${ }^{1}$, Tammy D. Utteridge, BVSc, PhD' ${ }^{2}$, Gloria M. del Fierro, DVM, PhD' Bianca A. Vassallo, BAnVetBioSci ${ }^{2}$ \& Robert Stevenson, BSc(Hons) ${ }^{1}$

Viral, bacterial and parasitological infections in rats and mice used in biomedical research continue to occur despite improved housing and biosurveillance. The presence of disease in laboratory animals can lead to spurious results for research undertaken in universities, research institutes and the pharmaceutical industry. Here the authors report the results of serological, microbiological, parasitological and molecular tests done on mice and rats from Australasia submitted to a rodent health monitoring laboratory (Cerberus Sciences) from 2004 to 2009. In tested mice, norovirus was the most prevalent virus and ectromelia virus was the least prevalent virus. In tested rats, pneumonia virus of mice was the most prevalent virus and adenoviruses 1 and 2 were the least prevalent viruses. In mice, Helicobacter hepaticus was the most prevalent bacterium, and in rats, Proteus spp. were the most prevalent bacteria. The most common positive helminthological finding in mice and rats was the presence of all pinworms (including Aspicularis spp. and Syphacia spp.). The most common positive protozoan findings in mice and rats were Chilomastix spp. and Trichomonads.

Use of improved methods for health monitoring and housing protects the health of rats and mice in research establishments and improves the quality of research in the laboratories that depend on these animal facilities ${ }^{1}$. There are numerous examples of disease in research animal populations compromising the research results derived from the projects ${ }^{2}$. The presence of mouse hepatitis virus ${ }^{3}$, mouse parvovirus and minute virus of mice ${ }^{4}$, Helicobacter spp. ${ }^{5}$, Mycoplasma pulmonis and Sendai virus $^{6}$ and mousepox ${ }^{7}$ have all confused research results. Routine monitoring of the prevalence of the various rat and mouse pathogens is useful to the research and laboratory animal community because it allows researchers to assess whether various diseases are increasing or decreasing in importance (in a particular animal population in a particular country). Mice and rats are susceptible to approximately 40 different viral, bacterial and parasitic diseases ${ }^{2}$. Many agents cause severe disease, often resulting in death, but other diseases may be subclinical, maintained in an animal colony for a long period of time or clinically silent, yet affect research results in subtle ways ${ }^{2}$. There is also a risk that infectious agents may contaminate animal products such as cell lines and antibodies. Health monitoring may be expensive, and the knowledge of which diseases are common or rare in a local setting is very useful so that frequency of testing and sample size can be adjusted accordingly.

${ }^{1}$ Cerberus Sciences, Thebarton, South Australia, Australia. ${ }^{2}$ Cerberus Sciences, Scoresby, Victoria, Australia. Correspondence should be addressed to E.F.M. (liz@cerberus.net.au). 
The increase in number and availability of genetically modified rodent models has expanded the use and number of animals in research facilities all over the world ${ }^{2}$. In addition, the rapid rise in the use of transgenic and knockout mice has resulted in greater numbers of immunocompromised animals in research facilities. Transgenic animals are often more susceptible to a greater number of infectious agents than are non-transgenic rodents and are also prone to certain rare diseases ${ }^{8}$. As populations of transgenic rodents grow, it becomes more difficult to eliminate many of these diseases 9 . For these reasons, it is important to monitor immunocompromised populations more frequently using different disease panels than those used for healthy rats and mice.

We carried out a retrospective analysis that presents an accurate assessment of the common and rare diseases in rat and mice colonies in research establishments in Australasia. A previous report identified mouse norovirus, mouse parvovirus, mouse hepatitis virus, rotavirus, Theiler's murine encephalomyelitis virus (TMEV), Helicobacter spp., Pasteurella pneumotropica and pinworms as common pathogens in mice from animal facilities in North America and Europe ${ }^{10}$. The same report identified rat respiratory virus, rat parvoviruses, rat theilovirus (also known as TMEV), Helicobacter spp., P. pneumotropica and pinworms as common pathogens in rats from animal facilities in North America and Europe ${ }^{10}$. We wished to establish whether similar diseases exist in laboratory rats and mice in Australasia. Knowledge about the sensitivity and specificity of the tests used, as well as the predictive value of positive and negative test results, is useful to allow laboratory animal workers to assess the seriousness of the consequences of a positive result ${ }^{10}$. We retrospectively analyzed the serological, microbiological, parasitological and molecular diagnostic data from approximately 1,000 laboratory mice and rats submitted from academic, industrial and government institutions in Australia, New Zealand and Singapore to this laboratory (Cerberus Sciences, a rodent health monitoring company) each year from 2004 to 2009.

\section{METHODS}

\section{Animals}

Live animals (rats and mice) were submitted to Cerberus Sciences by university animal programs, research centers, contract research organizations and biotechnology companies based in Australia, New Zealand and Singapore during the 5-y period from 2004 to 2009. Approximately $75 \%$ of submitted animals were mice. Information on age, strain or precise origin of the animal (whether it was housed in specific-pathogen-free (SPF) or conventional rooms) was rarely available. Here we use SPF to refer to colonies or populations described by the submitter as SPF- or high-barrier-maintained.
Animals were inspected by veterinary surgeons before being euthanized with an overdose of carbon dioxide in a chamber and then undergoing necropsy. At necropsy, serology, molecular biology, parasitology and microbiology samples were collected. Samples were tested as described below. Prevalence is defined as the percentage of the total number of samples tested (serum, fecal or fresh tissue samples) that were found to be positive for the organism tested ${ }^{9}$.

\section{Necropsy}

At necropsy, a nasal tracheal wash was carried out and samples were collected for polymerase chain reaction (PCR) analysis (cecal feces, spleen, liver and salivary gland). If the surgeon observed any macroscopic lesion at necropsy (e.g., pneumonia or a preputial abscess), he or she would collect an additional sample of a swab of the diseased tissue for microbiology analysis.

\section{Serology}

For serology analysis, serum samples were collected by cardiocentesis. The blood samples were allowed to clot for $30 \mathrm{~min}$ and then centrifuged for $5 \mathrm{~min}$ at 604.8g. The serum was collected and stored at $-20^{\circ} \mathrm{C}$. The primary test of choice for serology analysis was the enzyme-linked immunosorbent assay (ELISA), confirmed by the indirect fluorescence antibody test (IFAT). Depending on client request, mouse serum samples were tested for the following viral diseases using the ELISA: ectromelia virus (ECT), hantavirus (HAN), K virus (K), lymphocytic choriomeningitis virus (LCMV), mouse adenoviruses 1 and 2 (MAD), mouse cytomegalovirus (MCMV), mouse hepatitis virus $(\mathrm{MHV})$, mouse norovirus (MNV), mouse parvovirus (MPV), mouse minute virus (MVM), pneumonia virus of mice (PVM), polyoma virus (POLY), reovirus type 3 (REO 3), rotavirus (ROTA:EDIM), Sendai virus (SEND), TMEV (GD-VII) and mouse thymic virus (MTV). The ELISA was also used to detect the bacterial diseases cilia-associated respiratory bacillus and M. pulmonis and the protozoan organism Encephalitozoon cuniculi in mice.

Rat serum samples were tested for the following viral diseases using the ELISA: hantavirus, lymphocytic choriomeningitis virus, mouse adenoviruses 1 and 2, parvovirus (generic NS1), Toolan's $\mathrm{H}-1$ virus ( $\mathrm{H}-1)$, Kilham rat virus (KRV), rat minute virus (RMV), rat parvovirus (RPV), pneumonia virus of mice, rat coronavirus or sialodacryoadenitis virus (RCV/SDAV), reovirus type 3, Sendai virus and TMEV. The ELISA was also used to detect the bacterial diseases cilia-associated respiratory bacillus and M. pulmonis and the protozoan organism E. cuniculi in rats.

Sensitivity and specificity of the ELISAs were routinely monitored using the TG-ROC methodology ${ }^{11}$. In addition, all equivocal serology results were retested 
using IFAT. For the ELISAs, $20 \mu \mathrm{l}$ of prediluted serum (1:100 in phosphate-buffered saline (PBS) and 0.5\% skim milk) was added to each of the appropriate antigen wells and adjacent tissue control wells. The plate was covered and incubated for $1 \mathrm{~h}$ at $37^{\circ} \mathrm{C}$. After several washes with PBS and $0.05 \%$ Tween $20,100 \mu$ l of horseradish peroxidase-conjugated, affinity-purified, goat antibody to rodent IgG (Rockland Immunochemicals, Gilbertsville, PA, US) was added to each well. After $1 \mathrm{~h}$ of incubation at $37^{\circ} \mathrm{C}$, the plate was washed again, and $100 \mu \mathrm{l}$ of TMB substrate (ELISA Systems, Windsor, Queensland, Australia) was added to each well. The plate was incubated at room temperature in the dark until a distinct blue color developed in the antigen wells containing the positive sera. The reaction was stopped with $50 \mu \mathrm{l}$ of $1 \mathrm{M} \mathrm{H}_{2} \mathrm{SO}_{4}$ added to each well. The plate was read on a plate reader (BioTek Instruments, Inc., Winooski, VT, US) at $540 \mathrm{~nm}$ and compared with positive and negative controls. Results were considered to be positive if they exceeded the negative control cutoff value.

The IFAT was used to confirm equivocal or borderline positive results and a proportion of the positive results from multiple animals from the same submission. For the IFATs, a slide with 12 or 18 wells coated with the appropriate virus (Charles River Laboratories International, Inc., Wilmington, MA, US) was removed from the freezer and thawed. Then $20 \mu$ l of control and test sera were added to each well. The slides were incubated in the dark in a humid chamber for $30 \mathrm{~min}$. The slides were then washed with PBS and incubated with $20 \mu \mathrm{l}$ of fluorescein isothiocyanate (FITC)labeled conjugate (1:200 dilution). For the mouse IFATs, the FITC-labeled conjugate was obtained from DakoCytomation (Glostrup, Denmark) and for the rat IFATs, the FITC-labeled conjugate was obtained from Rockland Immunochemicals. The slides were then incubated in the dark in a humid chamber for $30 \mathrm{~min}$, washed with PBS, mounted and examined using a fluorescent microscope (Olympus CX41).

\section{Microbiology}

The microbiology samples were almost always collected during necropsy at the Cerberus Sciences testing facility. A nasal tracheal wash was done, and cecal feces were collected. The nasal tracheal wash involved reflecting the skin on either side of the midline, collecting the salivary glands and removing the musculature obscuring the trachea to expose the trachea. Then $100 \mu \mathrm{l}$ of peptone water (Thermo Fisher Australia Pty Ltd., Scoresby, Victoria, Australia) was introduced into the middle of the trachea, flushed through the upper respiratory tract several times and withdrawn back into the syringe. All the samples were collected under aseptic conditions.

All routine microbiological samples were incubated under microaerophilic and aerobic conditions.
Target organisms in mice and rats included Bordetella bronchiseptica, Citrobacter rodentium, Corynebacterium kutscheri, Klebsiella oxytoca, Klebsiella pneumoniae, P. pneumotropica, other Pasteurella spp., Salmonella spp., Staphylococcus aureus, Streptococcus pneumoniae, $\beta$-hemolytic Streptococcus spp. (Lancefield groups A, B, C, D, F and G), Proteus spp. and Pseudomonas spp.

In addition to routine samples taken at necropsy, microbiological analysis was also done on swab samples obtained directly from abscesses, enlarged spleens, preputial gland abscesses, pneumonic lungs, ulcerated skin and other macroscopic lesions. Microbiological analysis also included occasional swab samples sent to Cerberus Sciences by clients. The nasal tracheal wash was cultured on HBA/McConkey media (Thermo Fisher Australia Pty Ltd.) to isolate B. bronchiseptica, C. rodentium, C. kutscheri, K. oxytoca, K. pneumoniae, P. pneumotropica, other Pasteurella spp., S. pneumonia, $\beta$-hemolytic Streptococcus spp. (Lancefield groups A, B, C, D, F and G) and Proteus spp. Proteus spp. can also be detected in cecal fecal samples, as can Pseudomonas spp., C. rodentium, $K$. oxytoca, $K$. pneumoniae and Escherichia coli; cecal fecal were cultured on chromagenic UTI and XLD media (Thermo Fisher Australia Pty Ltd.). For Salmonella spp., the cecal fecal samples were inoculated into selenite broths and after $24 \mathrm{~h}$ of incubation, cultured onto XLD agar (Thermo Fisher Australia Pty Ltd.).

All cultures were kept at $37^{\circ} \mathrm{C}$ for $48 \mathrm{~h}$, and any further testing for identification of bacteria (e.g., Microbact (Thermo Fisher Australia Pty Ltd.) and API (bioMerieux, Baulkham Hills, New South Wales, Australia)) was done within 48 h. P. pneumotropica and Pasteurellaceae were further identified by using the PCR. The Optichin disc sensitivity method (Thermo Fisher Australia Pty Ltd.) was used to identify S. pneumoniae.

\section{Molecular diagnostics}

The primary assays for Helicobacter spp., Helicobacter hepaticus, Helicobacter bilis (cecal feces) and C. rodentium (mouse samples only, bacterial culture) were done using the PCR. To identify M. pulmonis, the PCR was done on nasal tracheal washes. To identify Pasteurellaceae, $P$. pneumotropica and C. rodentium (mouse samples only), the PCR was done on the microbiological culture.

The DNA was extracted from the above samples using a prepGEM Tissue kit (ZyGEM Corporation Ltd, Hamilton, New Zealand). The sample was mixed in $1 \mathrm{ml}$ of prepGEM and $99 \mathrm{ml}$ of the supplied $1 \mathrm{X}$ buffer and then incubated at $75{ }^{\circ} \mathrm{C}$ for 15 min followed by $98^{\circ} \mathrm{C}$ for $5 \mathrm{~min}$.

The PCR was carried out on the extracted DNA, on a Peltier thermal cycler (MJ Research, Waltham, MA, US). The PCR reaction mixture contained following components with a final concentration of $20 \mathrm{mM}$ Tris- $\mathrm{HCl}$ 
TABLE 1 | Prevalence of viral agents in mice submitted to Cerberus Sciences for health monitoring from 2004 to 2009

\begin{tabular}{|c|c|c|c|}
\hline Agent & Method & $N$ & $\begin{array}{l}\text { Prevalence } \\
(\%)\end{array}$ \\
\hline Ectromelia & Serology & 12,727 & 0.01 \\
\hline Hantavirus & Serology & 11,802 & 0 \\
\hline $\mathrm{K}$ virus & Serology & 953 & 0 \\
\hline $\begin{array}{l}\text { Lymphocytic chorio- } \\
\text { meningitis virus }\end{array}$ & Serology & 13,523 & 0 \\
\hline $\begin{array}{l}\text { Mouse adenoviruses } \\
1 \text { and } 2\end{array}$ & Serology & 14,332 & 0.07 \\
\hline Mouse cytomegalovirus & Serology & 21,226 & 0.02 \\
\hline Mouse hepatitis virus & Serology & 35,298 & 3.86 \\
\hline Mouse norovirus & Serology & 10,559 & 25.92 \\
\hline Mouse parvovirus & Serology & 31,338 & 0.9 \\
\hline Mouse minute virus & Serology & 29,966 & 0.03 \\
\hline $\begin{array}{l}\text { Pneumonia virus of } \\
\text { mice }\end{array}$ & Serology & 23,228 & 0 \\
\hline Polyoma virus & Serology & 7,169 & 0.01 \\
\hline Reovirus 3 & Serology & 13,257 & 0.02 \\
\hline Rotavirus & Serology & 30,963 & 1.24 \\
\hline Sendai virus & Serology & 15,186 & 0 \\
\hline $\begin{array}{l}\text { Theiler's murine } \\
\text { encephalomyelitis virus } \\
\text { (TMEV) }\end{array}$ & Serology & 26,639 & 0.23 \\
\hline Mouse thymic virus & Serology & 1,171 & 0.51 \\
\hline
\end{tabular}

( $\mathrm{pH} 8.5$ at $25^{\circ} \mathrm{C}$ ): $50 \mathrm{mM} \mathrm{KCl,} 2 \mathrm{mM} \mathrm{MgCl}, 200 \mu \mathrm{M}$ each of dNTP (dATP, dCTP, dTTP and dGTP), $0.5 \mathrm{U}$ of Taq polymerase (Fisher Biotec, Wembley, Western Australia, Australia) and $0.2 \mu \mathrm{M}$ of each primer (sense and antisense directions). The conditions used for all the PCR reactions, in general, included an initial denaturing step at $94^{\circ} \mathrm{C}$ for $5 \mathrm{~min}$, then a cycling step which consisted of 40 cycles of $94{ }^{\circ} \mathrm{C}$ for $30 \mathrm{~s}, 55^{\circ} \mathrm{C}$ for $30 \mathrm{~s}$ and $72^{\circ} \mathrm{C}$ for $1 \mathrm{~min}$. The PCR products were separated by electrophoresis in 2\% agarose E-gel (Invitrogen, Mulgrave, Victoria, Australia) and visualized with ultraviolet light.

The primers for Helicobacter spp., H. hepaticus, $H$. bilis $^{12}$, C. rodentium (mouse samples only) ${ }^{13}$, M. pulmonis $^{14}$, P. pneumotropica ${ }^{15}$ and Pasteurellaceae ${ }^{16}$ were designed on the basis of published information and were manufactured by GeneWorks (Thebarton, South Australia, Australia).

\section{Parasitology}

Most parasitology samples were collected at necropsy, although occasional fecal samples were received from living animals. The parasitology tests included a
TABLE 2 | Prevalence of viral agents in rats submitted to Cerberus Sciences for health monitoring from 2004 to 2009

\begin{tabular}{|c|c|c|c|}
\hline Agent & Method & $N$ & $\begin{array}{c}\text { Prevalence } \\
(\%)\end{array}$ \\
\hline Hantavirus & Serology & 1,602 & 0 \\
\hline $\begin{array}{l}\text { Lymphocytic chorio- } \\
\text { meningitis virus }\end{array}$ & Serology & 1,690 & 0 \\
\hline $\begin{array}{l}\text { Mouse adenoviruses } \\
1 \text { and } 2\end{array}$ & Serology & 1,405 & 0.07 \\
\hline Parvovirus & Serology & 2,674 & 0.26 \\
\hline Toolan's H-1 & Serology & 75 & 0 \\
\hline Kilham rat virus & Serology & 76 & 0 \\
\hline Rat minute virus & Serology & 71 & 0 \\
\hline Rat parvovirus & Serology & 56 & 0 \\
\hline Pneumonia virus of mice & Serology & 2,605 & 1.11 \\
\hline Rat coronavirus & Serology & 2,650 & 0.08 \\
\hline Reovirus 3 & Serology & 1,776 & 0 \\
\hline Sendai virus & Serology & 1,866 & 0 \\
\hline $\begin{array}{l}\text { Theiler's murine enceph- } \\
\text { alomyelitis virus (TMEV) }\end{array}$ & Serology & 2,404 & 0.08 \\
\hline
\end{tabular}

cellophane tape test for ectoparasites (mites, fleas, lice and mallophages) which was carried out by rubbing the adherent side of cellophane tape onto the fur of the rat or mouse. In addition, intestinal pinworm eggs (Syphacia spp.) and occasional mites were collected using cellophane tape placed with the adherent side downwards, around the mouse or rat anus on the perineal skin. The cellophane tape samples were then placed on a glass slide and examined by light microscope.

Further parasitological tests included the fecal flotation test, which was done on feces flushed through the entire small and large intestinal system using a syringe and $10 \mathrm{ml}$ of 10\% neutral-buffered formalin (Confix Green; Australian Biostain Pty Ltd, Traralgon, Victoria, Australia). The fecal contents were mixed with $10 \%$ neutral-buffered formalin, and $2.5 \mathrm{ml}$ of this solution was added to $2.5 \mathrm{ml}$ of a saturated $\mathrm{NaNO}_{3}$ solution. A cover slip was placed on the meniscal surface of the solution and left in place for $20 \mathrm{~min}$. The cover slip was then placed on a glass slide and examined microscopically.

Parasite eggs and protozoa were also examined by adding a drop of iodine solution (Thermo Fisher Australia Pty Ltd.) to two, separate, small sections of cecum and duodenum (with adherent feces), which were placed on a glass slide, covered with cover slips, sealed with clear nail varnish and examined under the light microscope. The fecal flotation test and the wet preparation test detected Amoeba (Entamoeba spp.), cestodes, coccidia, Giardia muris, nematodes, Spironucleus spp., Trichomonads and Chilomastix spp. 
TABLE 3 | Prevalence of bacteria in mice submitted to Cerberus Sciences for health monitoring from 2004 to 2009

\begin{tabular}{|c|c|c|c|}
\hline & Method & $N$ & $\begin{array}{c}\text { Prevalence } \\
(\%)\end{array}$ \\
\hline Bordetella bronchiseptica & Culture & 5,981 & 0 \\
\hline $\begin{array}{l}\text { Cilia-associated } \\
\text { respiratory bacillus }\end{array}$ & Serology & 7,395 & 0.04 \\
\hline \multirow[t]{2}{*}{ Citrobacter rodentium } & Culture & 4,282 & 0 \\
\hline & PCR & 1,989 & 0 \\
\hline $\begin{array}{l}\text { Corynebacterium } \\
\text { kutscheri }\end{array}$ & Culture & 6,218 & 0 \\
\hline Helicobacter spp. & PCR & 10,886 & 21.01 \\
\hline Helicobacter hepaticus & PCR & 330 & 31.52 \\
\hline Helicobacter bilis & PCR & 167 & 20.96 \\
\hline Klebsiella oxytoca & Culture & 2,154 & 1.35 \\
\hline Klebsiella pneumoniae & Culture & 5,573 & 0.07 \\
\hline \multirow[t]{3}{*}{ Mycoplasma pulmonis } & Serology & 15,623 & 0.03 \\
\hline & Culture & nt & nt \\
\hline & PCR & 1,904 & 0.47 \\
\hline Pasteurella multocida & Culture & & $\mathrm{nr}$ \\
\hline $\begin{array}{l}\text { Pasteurella pneumo- } \\
\text { tropica }\end{array}$ & $\begin{array}{l}\text { Culture/ } \\
\text { PCR }\end{array}$ & 5,112 & 18.3 \\
\hline Pasteurellaceae & $\begin{array}{l}\text { Culture/ } \\
\text { PCR }\end{array}$ & 5,112 & 0.04 \\
\hline Salmonella spp. & Culture & 4,996 & 0 \\
\hline Staphylococcus aureus & Culture & 2,818 & 9.08 \\
\hline $\begin{array}{l}\text { Streptobacillus } \\
\text { moniliformis }\end{array}$ & Culture & 6,163 & 0 \\
\hline $\begin{array}{l}\text { Streptococcus } \\
\text { pneumoniae }\end{array}$ & Culture & 6,605 & 0 \\
\hline $\begin{array}{l}\beta \text {-hemolytic } \\
\text { Streptococcus spp. } \\
\text { (group B) }\end{array}$ & Culture & & $\mathrm{nr}$ \\
\hline $\begin{array}{l}\beta \text {-hemolytic } \\
\text { Streptococcus spp. } \\
\text { (group G) }\end{array}$ & Culture & & $\mathrm{nr}$ \\
\hline $\begin{array}{l}\beta \text {-hemolytic } \\
\text { Streptococcus spp. (all) }\end{array}$ & Culture & 3,484 & 0.8 \\
\hline Proteus spp. & Culture & 2,215 & 18.33 \\
\hline Pseudomonas spp. & Culture & 5,902 & 0.54 \\
\hline
\end{tabular}

\section{RESULTS}

\section{Commonly requested testing}

For submitted mice, the most commonly requested viral serological test was that for mouse hepatitis virus ( 35,298 samples), followed by mouse parvovirus (31,338 samples), rotavirus (30,963 samples), minute
TABLE 4 | Prevalence of bacteria in rats submitted to Cerberus Sciences for health monitoring from 2004 to 2009

\begin{tabular}{|c|c|c|c|}
\hline & Method & $N$ & $\begin{array}{l}\text { Prevalence } \\
(\%)\end{array}$ \\
\hline Bordetella bronchiseptica & Culture & 685 & 0 \\
\hline $\begin{array}{l}\text { Cilia-associated } \\
\text { respiratory bacillus }\end{array}$ & Serology & 1,580 & 1.71 \\
\hline $\begin{array}{l}\text { Corynebacterium } \\
\text { kutscheri }\end{array}$ & Culture & 712 & 0 \\
\hline Helicobacter spp. & PCR & 728 & 12.09 \\
\hline Helicobacter hepaticus & PCR & $\mathrm{nr}$ & $\mathrm{nr}$ \\
\hline Helicobacter bilis & PCR & $\mathrm{nr}$ & $\mathrm{nr}$ \\
\hline Klebsiella oxytoca & Culture & $\mathrm{nr}$ & $\mathrm{nr}$ \\
\hline Klebsiella pneumoniae & Culture & 646 & 0 \\
\hline \multirow[t]{3}{*}{ Mycoplasma pulmonis } & Serology & 2,734 & 0.95 \\
\hline & Culture & $\mathrm{nr}$ & $\mathrm{nr}$ \\
\hline & PCR & 100 & 7 \\
\hline Pasteurella multocida & Culture & & $\mathrm{nr}$ \\
\hline $\begin{array}{l}\text { Pasteurella pneumo- } \\
\text { tropica }\end{array}$ & $\begin{array}{l}\text { Culture/ } \\
\text { PCR }\end{array}$ & 752 & 17.9 \\
\hline Pasteurellaceae & $\begin{array}{l}\text { Culture/ } \\
\text { PCR }\end{array}$ & 752 & 5.4 \\
\hline Salmonella spp. & Culture & 610 & 0 \\
\hline Staphylococcus aureus & Culture & 183 & 22.95 \\
\hline $\begin{array}{l}\text { Streptobacillus } \\
\text { moniliformis }\end{array}$ & Culture & 710 & 0 \\
\hline $\begin{array}{l}\text { Streptococcus } \\
\text { pneumoniae }\end{array}$ & Culture & 711 & 0 \\
\hline $\begin{array}{l}\beta \text {-hemolytic } \\
\text { Streptococcus spp. } \\
\text { (group B) }\end{array}$ & Culture & & $\mathrm{nr}$ \\
\hline $\begin{array}{l}\beta \text {-hemolytic } \\
\text { Streptococcus spp. } \\
\text { (group G) }\end{array}$ & Culture & & $\mathrm{nr}$ \\
\hline $\begin{array}{l}\beta \text {-hemolytic } \\
\text { Streptococcus spp. (all) }\end{array}$ & Culture & 389 & 1.8 \\
\hline Proteus spp. & Culture & 182 & 38.46 \\
\hline Pseudomonas spp. & Culture & 643 & 2.33 \\
\hline
\end{tabular}

virus and TMEV (Table 1). The least requested viral serological test for mice was that for K virus (953 samples; Table 1). For submitted rats, the most commonly requested viral serological test was that for parvovirus (2,650 samples), followed by coronavirus, pneumonia virus, TMEV and Sendai virus (Table 2). The least requested viral serological test for rats was that for rat parvovirus (56 samples; Table 2). For mice, 
TABLE 5 | Prevalence of eukaryotes in mice submitted to Cerberus Sciences for health monitoring from 2004 to 2009

\begin{tabular}{|c|c|c|c|}
\hline & Method & $N$ & $\begin{array}{c}\text { Prevalence } \\
(\%)\end{array}$ \\
\hline $\begin{array}{l}\text { Encephalitozoon } \\
\text { cuniculi }\end{array}$ & Serology & 6,918 & 0 \\
\hline Lice & Tape test & 7,290 & 0.3 \\
\hline \multicolumn{4}{|l|}{ Mites } \\
\hline Pinworm & $\begin{array}{l}\text { Wet mount/ } \\
\text { fecal } \\
\text { flotation }\end{array}$ & 7,683 & 1.47 \\
\hline \multicolumn{4}{|l|}{ Aspicularis tetraptera } \\
\hline \multicolumn{4}{|l|}{ Syphacia oblevata } \\
\hline \multicolumn{4}{|l|}{ Protozoa } \\
\hline Chilomastix spp. & Wet mount & 159 & 22.64 \\
\hline Entamoeba spp. & Wet mount & 5,045 & 0.44 \\
\hline Giardia spp. & Wet mount & 5,769 & 0 \\
\hline Hexamastix spp. & Wet mount & & $\mathrm{nr}$ \\
\hline $\begin{array}{l}\text { Monocercomonoides } \\
\text { spp. }\end{array}$ & Wet mount & & $\mathrm{nr}$ \\
\hline Retortamonas spp. & Wet mount & & $\mathrm{nr}$ \\
\hline Spironucleus spp. & Wet mount & 5,531 & 0 \\
\hline Trichomonads & Wet mount & 1,317 & 18.98 \\
\hline
\end{tabular}

the most commonly requested bacterial PCR analysis was that for Helicobacter spp. (10,886 samples), and the most commonly requested bacterial serological analysis was that for M. pulmonis (15,623 samples; Table 3). For rats, the most commonly requested bacteriological tests were those for M. pulmonis and cilia-associated respiratory bacillus (Table 4). A total of 7,683 parasitological tests were requested for mice (Table 5), and 842 parasitological tests were requested for rats (Table 6).

\section{Virology}

In mice, mouse norovirus was the most prevalent virus, followed by mouse hepatitis virus, mouse rotavirus, mouse parvovirus, mouse thymic virus, TMEV, mouse adenoviruses 1 and 2, mouse minute virus, cytomegalovirus, reovirus and polyoma virus, and ectromelia virus (Table 1). In rats, the most prevalent virus was pneumonia virus of mice, followed by parvovirus, rat coronavirus, TMEV and mouse adenoviruses 1 and 2 (Table 2).

\section{Microbiology and molecular diagnostics}

In mice, culture analysis indicated that $H$. hepaticus was the most prevalent bacterium, followed by
TABLE 6 | Prevalence of eukaryotes in rats submitted to Cerberus Sciences for health monitoring from 2004 to 2009

\begin{tabular}{|c|c|c|c|}
\hline & Method & $N$ & $\begin{array}{c}\text { Prevalence } \\
(\%)\end{array}$ \\
\hline $\begin{array}{l}\text { Encephalitozoon } \\
\text { cuniculi }\end{array}$ & Serology & 1,340 & 0 \\
\hline Lice & Tape test & 799 & 0 \\
\hline \multicolumn{4}{|l|}{ Mites } \\
\hline Pinworm & $\begin{array}{l}\text { Wet mount/ } \\
\text { fecal } \\
\text { flotation }\end{array}$ & 842 & 10.8 \\
\hline \multicolumn{4}{|l|}{ Aspicularis tetraptera } \\
\hline \multicolumn{4}{|l|}{ Syphacia muris } \\
\hline \multicolumn{4}{|l|}{ Syphacia oblevata } \\
\hline \multicolumn{4}{|l|}{ Protozoa } \\
\hline Chilomastix spp. & Wet mount & 5 & 60 \\
\hline Entamoeba spp. & Wet mount & 545 & 0.18 \\
\hline Giardia spp. & Wet mount & 543 & 0 \\
\hline Hexamastix spp. & Wet mount & & $\mathrm{nr}$ \\
\hline $\begin{array}{l}\text { Monocercomonoides } \\
\text { spp. }\end{array}$ & Wet mount & & $\mathrm{nr}$ \\
\hline Retortamonas spp. & Wet mount & & $\mathrm{nr}$ \\
\hline Spironucleus spp. & Wet mount & 543 & 0 \\
\hline Trichomonads & Wet mount & 37 & 51.35 \\
\hline $\begin{array}{l}\text { Trichosomoides } \\
\text { crassicauda }\end{array}$ & Wet mount & 451 & 0 \\
\hline
\end{tabular}

H. bilis, Proteus spp., P. pneumotropica, S. aureus, K. oxytoca and $\beta$-hemolytic Streptococcus spp. (Table 3). In rats, culture and PCR analysis indicated that Proteus spp. were the most prevalent bacteria, followed by S. aureus, Helicobacter spp., P. pneumotropica and Pseudomonas bacteria (Table 4). The results of the PCR for Helicobacter spp., H. hepaticus and $H$. bilis on cecal feces and $C$. rodentium on microbiological culture and identification of M. pulmonis in nasal tracheal washes and Pasteurellaceae and P. pneumotropica identification in the microbiological culture of nasal tracheal washes are detailed (Tables 3 and 4). For Pasteurella spp. including P. pneumotropica, initial isolation was carried out by culture and definitive identification was confirmed by PCR. For Helicobacter spp., only the PCR methodology was used. For Pasteurella spp., there was a high correlation between microbiological culture and PCR.

\section{Parasitology}

Non-pathogenic or commensal organisms isolated from mice and rats included Entamoeba spp., 
Chilomastix spp., Hexamastix spp., Monocercomonoides spp. and Retortamonas spp., Spironucleus spp. and Trichomonads (Tables 5 and 6). The most common positive helminthological finding in mice and rats was the presence of pinworms (including Aspicularis spp. and Syphacia spp.). The most common protozoan finding in mice was Chilomastix spp. and Trichomonads.

\section{DISCUSSION}

This study is not comprehensive but is the first report to our knowledge on the microbiological status of laboratory mice and rats in Australasia. The most commonly requested viral serological test in mice was that for mouse hepatitis virus. In rats, the most commonly requested serological test was that for parvovirus. Testing requests probably reflect current knowledge of outbreaks and therefore skew results. The popularity of test requests was not reflected in the prevalence of various diseases, however; norovirus was the most prevalent virus in laboratory mice in this study.

These data may include false positive and false negative results, although every effort was made to use secondary tests to confirm positive results. Furthermore, the animals submitted to Cerberus Sciences may not be a representative sample of the research rodent population because institutes are more likely to submit animal during or after a disease outbreak and because not all research institutes in the region submit their routine health monitoring samples to Cerberus Sciences; other health monitoring companies may also be involved. In addition, some laboratory animal colonies are tested more frequently than others ${ }^{9}$, although Cerberus Sciences encourages research institutes to submit animals for routine monitoring throughout the year. We also note that these data cannot be compared directly with prevalence rates reported in other publications as each report presents data in different ways.

Our results indicate that in mice submitted between 2004 and 2009 in Australasia, norovirus was the most prevalent virus (25.92\%). Currently, mouse norovirus is the most prevalent viral pathogen identified in mice in laboratory animal facilities in the US and Canada ${ }^{17}$. In 2005 , the seroprevalence of norovirus in a large number of murine research colonies in the US and Canada was reported to be $22.1 \%$ (ref. 17), and in 2009, the prevalence of norovirus in mice in North America was reported to be $32 \%$ (the most prevalent virus in the survey) ${ }^{10}$. Norovirus can be fatal in immunodeficient mice but does not cause clinical signs or death in immunocompetent mice ${ }^{17}$.

Mouse hepatitis virus was the second most prevalent virus in mice in our study (3.86\%); it is an important virus in non-SPF-housed mice in the US². In Taiwan in 2007 , more than $20 \%$ of mouse colonies tested were positive for mouse parvovirus, mouse hepatitis virus, TMEV and $M$. pulmonis ${ }^{18}$. This is similar to prevalence reported in the US ${ }^{19}$, Europe ${ }^{10}$, Korea ${ }^{20}$, France $^{21}$ and Taiwan ${ }^{18}$.
In 2006, parvoviruses, Kilham rat virus, Toolan's H-1 virus and rat parvovirus were reported to be the most prevalent viruses in rats in Europe ${ }^{9}$. Non-SPF-housed rats are reported to be at risk for sialodacryoadenitis and coronavirus (which includes sialodacryoadenitis virus and rat coronavirus), parvovirus and M. pulmonis ${ }^{2}$. Almost $40 \%$ of tested rat colonies in Taiwan were positive for M. pulmonis and rat parvovirus, with fewer colonies positive for Kilham rat virus, sialodacryoadenitis virus, pneumonia virus of mice, Sendai virus and Syphacia spp. ${ }^{18}$. In 1978, rat sialodacryoadenitis virus was the most prevalent pathogen in rats in the $\mathrm{UK}^{22}$, but in our study, the most prevalent virus in rats was pneumonia virus of mice, followed by parvovirus, rat coronavirus, TMEV and mouse adenoviruses 1 and 2 .

In contrast to results from Taiwan ${ }^{18}$, we did not find any positive serological tests for hantavirus in rats or mice. We did find a low prevalence of TMEV in both mice and rats, although only mice are thought to be involved in endemic infections. Serological evidence of ectromelia virus and lymphocytic choriomeningitis virus in non-SPF-housed mice has been reported ${ }^{1}$, and we found serological evidence of ectromelia virus in mice in our study. An absence of serological evidence of lymphocytic choriomeningitis virus and ectromelia virus was noted in 1978 in the $\mathrm{UK}^{23}$, indicating that the prevalence of these pathogens was already declining in that region at that time. In 1980, mouse hepatitis virus was prevalent in mouse colonies and the prevalence of Sendai virus was increasing ${ }^{24}$. Mouse hepatitis virus is highly contagious, which likely accounts for its continued prevalence ${ }^{10}$.

In contrast, the prevalence of Sendai virus in rats and mice has recently declined in France ${ }^{21}$. The incidence and prevalence of Sendai virus has also declined in the US and Europe ${ }^{10}$, and our data indicate that its prevalence is declining in Australasia as well. In 2005, decreases in the prevalence of pneumonia virus of mice, reovirus type 3 , Sendai virus, sialodacryoadenitis and M. pulmonis in Europe were reported ${ }^{9}$. Additionally, $K$ virus and polyoma virus were reported to have been eliminated from laboratory animal colonies ${ }^{9}$, and lymphocytic choriomeningitis virus, $\mathrm{K}$ virus, ectromelia virus, mouse adenovirus and mouse thymic virus had not been detected for over 10 years.

Our results indicate that Helicobacter spp. were the most prevalent bacteria in mice and that Proteus spp. were the most prevalent bacteria in rats. This is in contrast with recent reports that most prevalent bacteria in rats and mice are Helicobacter spp., particularly H. hepaticus ${ }^{25}$. M. pulmonis is still prevalent in rats and mice in Australasia but is of declining importance in the US and Europe ${ }^{10}$. We found no positive tests for Streptobacillus moniliformis in either rats or mice, although an outbreak of this disease was reported in Australia in Swiss white mice in 1996 (ref. 26). 
The most common positive helminthological finding in mice and rats was the presence of all pinworms (including Aspicularis spp. and Syphacia spp.). The most common positive protozoan finding in mice and rats was the presence of Chilomastix spp. and Trichomonads. We used three different tests for the detection of helminths and protozoa: external anal tape tests, iodine wet preparations of cecal and duodenal mucosa and fecal contents, and fecal flotation tests. In addition, the veterinary pathologist often made mention of the presence of helminths and protozoa in the gastrointestinal system upon histopathological examination. Using multiple detection methods helps to minimize false-negative results. A previous report cautioned against the use of perianal tape impressions alone to screen for Syphacia spp. in sentinel rats and mice ${ }^{27}$. Syphacia spp. infestations in rats and mice have occurred in laboratory animal colonies for many years ${ }^{28}$ and remain a problem ${ }^{1}$.

Our results could potentially be influenced by the fact that most institutes use a soiled-bedding sentinel system, which tends to favor the detection of agents transmitted primarily by the oro-fecal route. The prevalence of agents transmitted primarily by aerosol or contact could be underestimated in this system. Using a combination of direct-contact and soiled-bedding sentinels and testing exhaled air is the best strategy for detecting infection ${ }^{18}$.

The barrier-housing status of animals submitted to Cerberus Sciences was not always stated and therefore was not analyzed in this study. In SPF-housed rats, parvovirus, coronavirus, pneumonia virus of mice, TMEV and pinworms are reportedly very common ${ }^{1}$. In SPF-housed mice, mouse hepatitis virus, parvovirus, ectoparasites, endoparasites and pathogenic Helicobacter spp. have been reported ${ }^{1,2}$. These reports are similar to our findings, which suggests that these agents are problematic in both SPF-housed and nonSPF-housed animals. There is a risk of cross-infection between SPF and non-SPF housing units ${ }^{1}$. The definition of SPF should be refined and standardized throughout the community ${ }^{1}$.

Establishing a judicious testing strategy, diagnosing pathogens rapidly, controlling identified outbreaks and using animals with known microbiological profiles can help to prevent disease outbreaks in animal facilities in research institutes ${ }^{1}$. The introduction of serological screening programs and advances in laboratory animal husbandry and disease knowledge have resulted in a decrease in the number of infected laboratory animal colonies ${ }^{9}$. Despite improvements in husbandry and surveillance, however, much more can be done to safeguard the health of rodents used in biomedical facilities ${ }^{29}$. Inadequate finances, facilities and staffing; a lack of compliance with recommended or required practices; and regulatory constraints all contribute to inadequate health monitoring in animal facilities ${ }^{1}$.

The prevalence of various diseases may have increased recently as institutes house large numbers of transgenic mice and rats that are often immunocompromised ${ }^{10}$. In Japan, genetically modified mice had positive serological tests for M. pulmonis, mouse parvovirus and $\mathrm{TMEV}^{30}$, indicating that genetically modified mice are highly susceptible to common laboratory animal pathogens ${ }^{8}$. Although live animals are tested regularly, few institutions test external animal products such as cell lines, serum and transplantable tumors ${ }^{1}$. The exchange of animals and biological products between animal institutes has been responsible for some disease outbreaks ${ }^{9}$.

Little information is available on the prevalence of disease in laboratory rats and mice in Australia, but the prevalence of viral antibodies and helminths in field populations of wild mice in southeastern Australia has been examined ${ }^{31}$. Mice were seropositive for mouse hepatitis virus, rotavirus, minute virus of mice, mouse adenovirus, reovirus and mouse cytomegalovirus, and the presence of Taenia taeniaformis, Syphacia oblevata and Vampirolepsis spp. was detected. These results were similar to those in another report, which additionally detected M. pulmonis, Sendai virus, lymphocytic choriomeningitis virus and parvovirus in wild mice ${ }^{32}$. The seroprevalence of mouse cytomegalovirus is far greater in wild populations $(61.7 \%)^{33}$ than in our study $(0.02 \%)$. In a serological survey of virus infection among wild house mice (Mus domesticus) in the $\mathrm{UK}$, mice were seropositive for mouse hepatitis virus, mouse cytomegalovirus, mouse thymic virus, mouse adenovirus, mouse parvovirus and minute virus of mice $^{34}$. Testing of rodent-borne pathogens carried by wild-caught Norway rats in the US detected antibodies against rat coronavirus, $M$. pulmonis, cilia-associated respiratory bacillus, rat parvovirus, Kilham rat virus, Toolan's H-1 virus, Sendai virus and TMEV ${ }^{35}$. These reports suggest that many of the pathogens that remain problematic for laboratory rodents are also encountered in wild mice and rats.

Although our panel includes tests for relatively new agents such as mouse norovirus and Helicobacter spp., future panels may need to include rat respiratory virus $^{36}$ and rat minute virus. Rat respiratory virus is the working name for a new respiratory pathogen of laboratory rats in North America, Europe and Asia causing pneumonitis and alveolar hyperplasia in the lungs ${ }^{36}$. The agent is now thought to be Pneumocystis carinii ${ }^{37}$. In future, lung samples from rats will need to be tested by histopathology and the PCR to assess the prevalence of $P$. carinii.

Regular reporting of prevalence of laboratory rodent pathogens is important so that health-monitoring programs can be updated ${ }^{9,38}$. Although our study is not a comprehensive study of laboratory animals 
in Australasia, this 5-y retrospective analysis gives an overview of the prevalence of common viral, bacterial and parasitological diseases in laboratory rats and mice. These data help to identify which agents are common or rare in laboratory rats and mice in Australasia. We agree with others who have recommended that research institutes obtain animals from reputable vendors, quarantine newly arrived animals, maintain animals in adequate housing with trained personnel and test regularly to determine the disease status of research animals.

\section{COMPETING FINANCIAL INTERESTS}

The authors declare no competing financial interests.

\section{Received 19 July; accepted 12 September 2011}

Published online at http://www.labanimal.com/

1. Jacoby, R.0. \& Lindsey, J.R. Risks of infection among laboratory rats and mice at major biomedical research institutions. ILAR J. 39, 266-271 (1998).

2. Jacoby, R.O. \& Lindsey, J.R. Health care for research animals is essential and affordable. FASEB J. 11, 609-614 (1997).

3. Barthold, S.W. Host age and genotypic effects on enterotropic mouse hepatitis virus infection. Lab. Anim. Sci. 37, 36-40 (1987).

4. Brownstein, D.G. et al. Pathogenesis of infection with a virulent allotropic variant of minute virus of mice and regulation by host genotype. Lab. Invest. $65,357-364$ (1991).

5. Diwan, B.A., Ward, J.M., Ramljak, D. \& Anderson, L.M. Promotion by Helicobacter hepaticus-induced hepatitis of hepatic tumors initiated by $\mathrm{N}$-nitroso-dimethylamine in male A/JCr mice. Toxicol. Pathol. 25, 597-605 (1997).

6. Howard, C.J., Stott, E.J. \& Taylor, G. The effect of pneumonia induced in mice with Mycoplasma pulmonis on resistance to subsequent bacterial infection and the effect of a respiratory infection with Sendai virus on the resistance of mice to Mycoplasma pulmonis. J. Gen. Microbiol. 109, 79-87 (1978).

7. Lipman, N.S., Perkins, S., Nguyen, H., Pfeffer, M. \& Meyer, H. Mouse pox resulting from use of ectromelia viruscontaminated, imported mouse serum. Comp. Med. 50, 426-435 (2000).

8. Gozalo, A.S. et al. Spontaneous Staphylococcus xylosus infection in mice deficient in NADPH oxidase and comparison with other laboratory mouse strains. J. Am. Assoc. Lab. Anim. Sci. 49, 480-486 (2010).

9. Schoondermark-van de Ven, E.M., Philipse-Bergmann, I.M. \& van der Logt, J.T. Prevalence of naturally occurring viral infections, Mycoplasma pulmonis and Clostridium piliforme in laboratory rodents in Western Europe screened from 2000 to 2003. Lab. Anim. 40, 137-143 (2006).

10. Pritchett-Corning, K.R., Cosentino, J. \& Clifford, C.B. Contemporary prevalence of infectious agents in laboratory mice and rats. Lab. Anim. 43, 165-173 (2009).

11. Greiner, M., Sohr, D. \& Göbel, P. A modified ROC analysis for the selection of cut-off values and the definition of intermediate results of serodiagnostic tests. J. Immunol. Meth. 185, 123-132 (1995).

12. Drazenovich, N.L., Franklin, C.L., Livingston, R.S. \& Besselsen, D.G. Detection of rodent Helicobacter spp. by use of fluorogenic nuclease polymerase chain reaction assays. Comp. Med. 52, 347-353 (2002).
13. McKeel, R., Douris, N., Foley, P.L. \& Feldman, S.H. Comparison of an espB gene fecal polymerase chain reaction assay with bacteriologic isolation for detection of Citrobacter rodentium infection in mice. Comp. Med. 52, 439-444 (2002).

14. Loganbill, J.K., Wagner, A.M. \& Besselsen, D.G. Detection of Mycoplasma pulmonis by fluorogenic nuclease polymerase chain reaction analysis. Comp. Med. 55, 419-424 (2005).

15. Weigler, B.J. et al. Further evaluation of a diagnostic polymerase chain reaction assay for Pasteurella pneumotropica. Lab. Anim. Sci. 48, 193-196 (1998).

16. Bootz, F., Kirschnek, S., Nicklas, W., Wyss, S.K. \& Homberger, F.R. Detection of Pasteurellaceae in rodents by polymerase chain reaction analysis. Lab. Anim. Sci. 48, 542-546 (1998).

17. Hsu, C.C., Wobus, C.E., Steffen, E.K., Riley, L.K. \& Livingston, R.S. Development of a microsphere-based serologic multiplexed fluorescent immunoassay and a reverse transcriptase PCR assay to detect murine norovirus 1 infection in mice. Clin. Diagn. Lab. Immunol. 12, 1145-1151 (2005).

18. Liang, C.T. et al. Microbial contaminations of laboratory mice and rats in Taiwan from 2004 to 2007. J. Am. Assoc. Lab. Anim. Sci. 48, 381-386 (2009).

19. Casebolt, D.B., Lindsey, J.R. \& Cassell, G.H. Prevalence rates of infectious agents among commercial breeding populations of rats and mice. Lab. Anim. Sci. 38, 327-329 (1988).

20. Won, Y.S. et al. Microbiological contamination of laboratory mice and rats in Korea from 1999 to 2003. Exp. Anim. 55, 11-16 (2006).

21. Zenner, L. \& Regnault, J.P. Ten-year long monitoring of laboratory mouse and rat colonies in French facilities: a retrospective study. Lab. Anim. 34, 76-83 (2000).

22. Carthew, P., Sparrow, S. \& Verstraete, A.P. Incidence of natural virus infections of laboratory animals 1976-1977. Lab. Anim. 12, 245-246 (1978).

23. Carthew, P. \& Verstraete, A. A serological survey of accredited breeding colonies in the United Kingdom for common rodent viruses. Lab. Anim. 12, 29-33 (1978).

24. Gannon, J. \& Carthew, P. Prevalence of indigenous viruses in laboratory animal colonies in the United Kingdom 1978-1979. Lab. Anim. 14, 309-311 (1980).

25. Livingston, R.S. \& Riley, L.K. Diagnostic testing of mouse and rat colonies for infectious agents. Lab Anim. (NY) 32, 44-51 (2003).

26. Glastonbury, J.R., Morton, J.G. \& Matthews, L.M. Streptobacillus moniliformis infection in Swiss white mice. J. Vet. Diagn. Invest. 8, 202-209 (1996).

27. Hill, W.A., Randolph, M.M. \& Mandrell, T.D. Sensitivity of perianal tape impressions to diagnose pinworm (Syphacia spp.) infections in rats (Rattus norvegicus) and mice (Mus musculus). J. Am. Assoc. Lab. Anim. Sci. 48, 378-380 (2009).

28. Nakagawa, M. et al. Ten years-long survey on pathogen status of mouse and rat breeding colonies. Jikken Dobutsu. 33, 115-120 (1984).

29. Carty, A.J. Opportunistic infections in rats and mice: Jacoby and Lindsey revisited. ILAR J. 9, 272-276 (2008).

30. Yamamoto, H. et al. Microbiological contamination in genetically modified animals and proposals for a microbiological test standard for national universities in Japan. Exp. Anim. 50, 397-407 (2001).

31. Singleton, G.R., Smith, A.L., Shellam, G.R., Fitzgerald, N. \& Müller, W.J. Prevalence of viral antibodies and helminths in field populations of house mice (Mus domesticus) in southeastern Australia. Epidemiol. Infect. 110, 399-417 (1993).

32. Smith, A.L., Singleton, G.R., Hansen, G.M. \& Shellam, G. A serologic survey for viruses and Mycoplasma pulmonis among wild house mice (Mus domesticus) in southeastern Australia. J. Wildl. Dis. 29, 219-229 (1993). 
33. Singleton, G.R., Smith, A.L. \& Krebs, C.J. The prevalence of viral antibodies during a large population fluctuation of house mice in Australia. Epidemiol. Infect. 125, 719-727 (2000).

34. Becker, S.D., Bennett, M., Stewart, J.P. \& Hurst, J.L. Serological survey of virus infection among wild house mice (Mus domesticus) in the UK. Lab. Anim. 41, 229-238 (2007). 35. Easterbrook, J.D., Kaplan, J.B., Glass, G.E., Watson, J. \& Klein, S.L. A survey of rodent-borne pathogens carried by wild-caught Norway rats: a potential threat to laboratory rodent colonies. Lab. Anim. 42, 92-98 (2008).
36. Albers, T.M., Simon, M.A. \& Clifford, C.B. Histopathology of naturally transmitted "rat respiratory virus": progression of lesions and proposed diagnostic criteria. Vet. Pathol. 46, 992-999 (2009).

37. Livingston, R.S. et al. Pneumocystis carinii infection causes lung lesions historically attributed to rat respiratory virus. Comp. Med. 61, 45-52 (2011).

38. Weisbroth, S.H., Peters, R., Riley, L.K. \& Shek, W. Microbiological assessment of laboratory rats and mice. ILAR J. 39, 272-290 (1998). 